\title{
Two new scaritine beetles of the genera Leleuporella Basilewsky, 1956, and Striganoviella, gen.n., from Vietnam (Coleoptera: Carabidae)
}

\section{Ава новых представителя жкужелищ подсемейства Scaritinae из Вьетнама (Coleoptera: Carabidae)}

\author{
D.N. Fedorenko \\ A.H. Федоренко
}

\begin{abstract}
A.N. Severtsov Institute of ecology and evolution, Leninsky pr. 33, Moscow 119071 Russia.
Институт проблем экологии и эволюции им. А.Н. Северцова, Российская Академия Наук, Ленинский пр-т, Москва 119071 Россия, dmitri-fedorenko@yandex.ru
\end{abstract}

KEY WORDS: Coleoptera, Carabidae, Leleuporella, Striganoviella, new genus, new species, Vietnam.

КЛЮЧЕВЫЕ СЛОВА: Coleoptera, Carabidae, Leleuporella, Striganoviella, новый род, новый вид, Вьетнам.

ABSTRACT. Two new scaritine carabids, Leleuporella tuberculata sp.n. and Striganoviella subopaca gen.n. \& sp.n., are described from Vietnam. The former genus belongs to the subtribe Clivinina, Clivinini, and is first recorded in Indochina, this being a far eastward extension of the genus range within the Oriental realm. The latter genus is a member of the tribe Dyschiriini and established here for the species which shows a particular combination of characters. Some of them are unique for the tribe while some others, e.g., secondarily entire postmentum, occur nowhere else but in the North American genus Akephorus LeConte, 1851.

РЕЗЮМЕ. Из Вьетнама описаны два новых представителя жужелиц подсемейства Scaritinae: Leleuporella tuberculata sp. n. и Striganoviella subopaca gen.n., sp.n. Первый род входит в состав подтрибы Clivinina трибы Clivinini. Его обнаружение в Индокитае существенно расширяет ареал рода на восток в пределах Ориентальной области. Другой род относится к трибе Dyschiriini и установлен для вида, обладающего специфическим сочетанием признаков. Часть из них уникальна, а некоторые другие, например, вторично цельный постментум, характерны только для североамериканского рода Akephorus LeConte, 1851.

\section{Introduction}

The ground-beetle fauna of Indochina, Vietnam in particular, is poorly studied. Many new species wait for their descriptions and the ranges of many higher taxa, genera and some tribes, require clarification as well. During a few recent expeditions of the Joint Russia-Vietnam Tropical Center in different regions of Vietnam a number of interesting carabids have been collected, among them two new species and one new genus described below.
The first species belongs to the clivinine genus Leleuporella Basilewsky, 1956, which has long been known to be exclusively Afrotropical in distribution. It was not until recently that two more species of the genus, L. sexangulata Balkenohl, 1997, and L. devagiriensis Abhitha \& Sabu, 2009, were described from Sri Lanka and South India, respectively. The disjunction of the genus range between tropical Africa on the one hand and South India on the other was explained as resulted from nothing else but the continental drift following the Gondwanaland split [Abhita \& Sabu, 2009].

The record of $L$. tuberculata sp.n. in Indochina is the next eastward extension of the genus range within the Oriental realm. In addition, it strongly opposes to the above faunogenetic hypothesis because Indochina was never part of Gondwana. As for the the disjunctions concerned they could have been formed otherwise, namely, by emerging from rather recent climatic changes rather than continental drift. This seems to be true of many riparian carabids, smaller scaritines particularly.

The second species described is a member of the tribe Dyschiriini. Moreover, it requires a new genus for itself due to an unusual and highly peculiar character combination it shows.

Holotypes and paratypes of the species described are deposited at the Zoological Museum of M.V. Lomonosov Moscow State University and in the author's reference collection at A.N. Severtsov Institute of Ecology and Evolution, Russian Academy of Sciences (Moscow), respectively.

Leleuporella tuberculata Fedorenko, sp.n. Figs 1, 3-6.

DESCRIPTION. Body length 2.5-2.9 mm. Uniform yellow to pale brown, shining, without metallic 

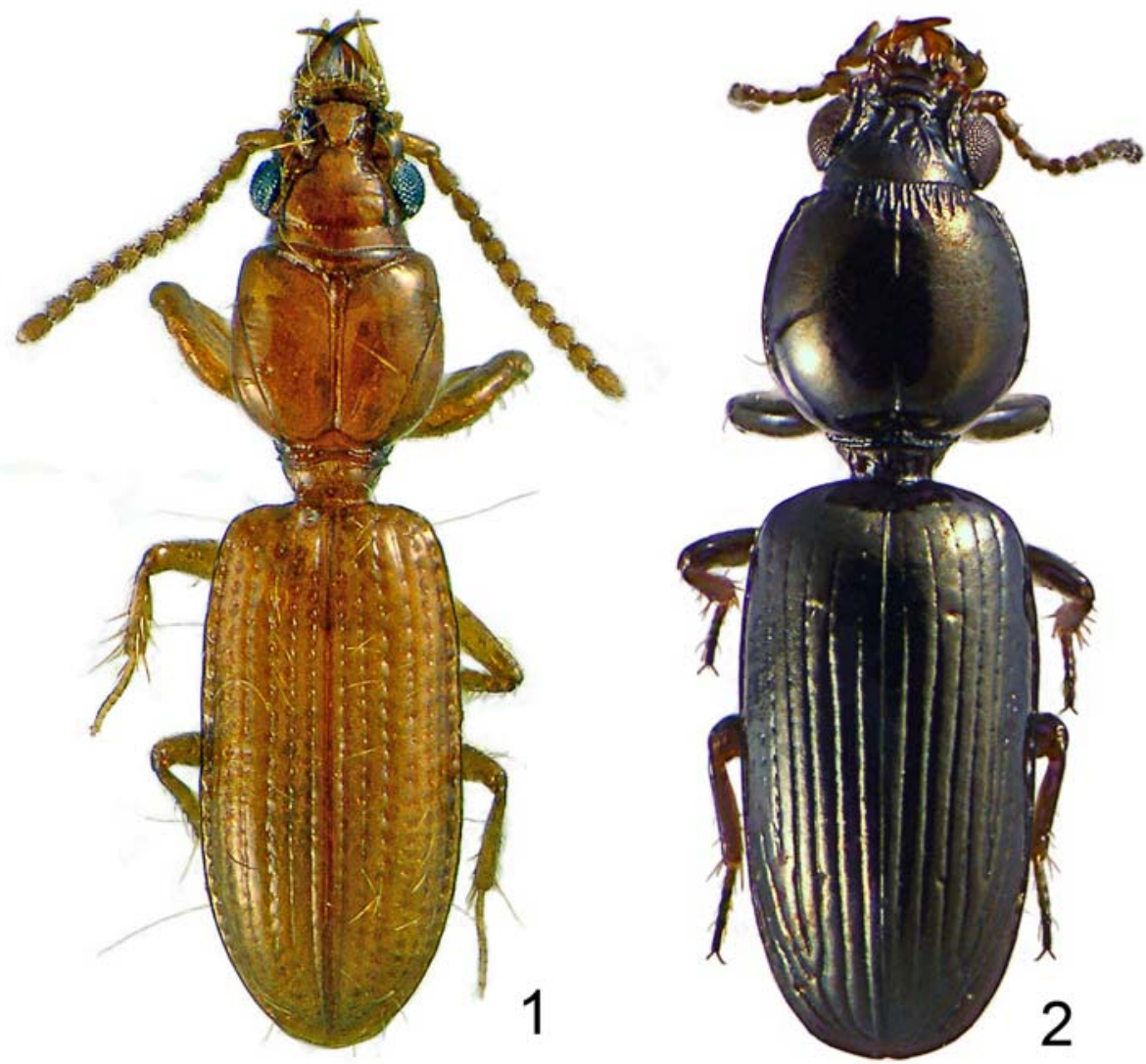

Figs 1-2. Body, dorsal aspect: Leleuporella tuberculata sp.n. (1), Striganoviella subopaca sp.n. (2).

Рис. 1-2. Габитус, вид сверху. Leleuporella tuberculata sp.n. (1), Striganoviella subopaca sp.n. (2).

lustre and microsculpture; sometimes only vertex with almost obsolete isodiametric meshes. Underside impunctate.

Mandibles long and narrow; labrum transverse, broadening forward, hardly trilobed (pentagonal), 7setose, inner five setae smaller than outer ones and arranged into a transverse row. Anterior margin of clypeus narrowly bordered and reflexed, slightly convex, almost indistinctly undulate, slightly emarginate at lateral wings, latter prominent, distinctly separated from even and convex supra-antennal plates; clypeal field elevated and plate-like throughout except at anterior margin, slightly narrower backwards, with a large but shallow depression in the middle; frontoclypeal suture rather wide, slightly arcuated backwards, deep anteriorly, shallower posteriorly, deeper and broader at sides. Frontal sulci very deep, nearly engraved, wider posteriorly and much so anteriorly, deepest between clypeus and supra-antennal plates. Supra-orbital setae two. Neck-constriction uninterrupted, moderately deep, deeper outwards, finely but deeply punctate. Frons and vertex even and smooth, level to anterior supraorbital seta with a shallow, transverse line widely interrupted at middle. Eyes of normal size, convex and prominent. Antennae moniliform, long, reaching pronotal base, pubescent from pedicell onward; antennomeres 2, 3 and 11 longitudinal, remaining subglobose, slightly longer than wide.

Mentum (Fig. 3) quadrisetose, anterior pair of setae at base of median tooth, carinate medially in anterior half, labial pits spheric, large, internal, with a common fissure-like opening at border with submentum; median tooth long, spatulate, subtruncate, surpassing lateral lobes; these moderately wide, emarginate anteriorly, both inner and outer angles pointed; ligula bisetose, narrow and long, longer than paraglossae; penultimate labial palpomere bisetose near base, last labial palpomere moderately tumid at base in ventral view, much more so at inner margin than at outer, last maxillary palpomere (Fig. 4) moderately tumid at inner margin only; last maxillary palpomere about thrice as long as penultimate one along outer margin.

Pronotum 0.97-1.03 times as wide as long, almost parallel-sided, with widely rounded hind angles; anterior margin slightly sinuate at middle, front angles oblique and narrowly rounded. Front transverse impression ( $=\mathrm{V}$-shaped furrow entire) very deep, deeper laterally, rather wide, impunctate. Mid-line very deep and very wide, engraved, much deeper and much broader anteriorly, adjoining and surpassing V-shaped furrow a little. Lateral setigerous pores two pairs situated close to but isolated from notopleural suture; latter 


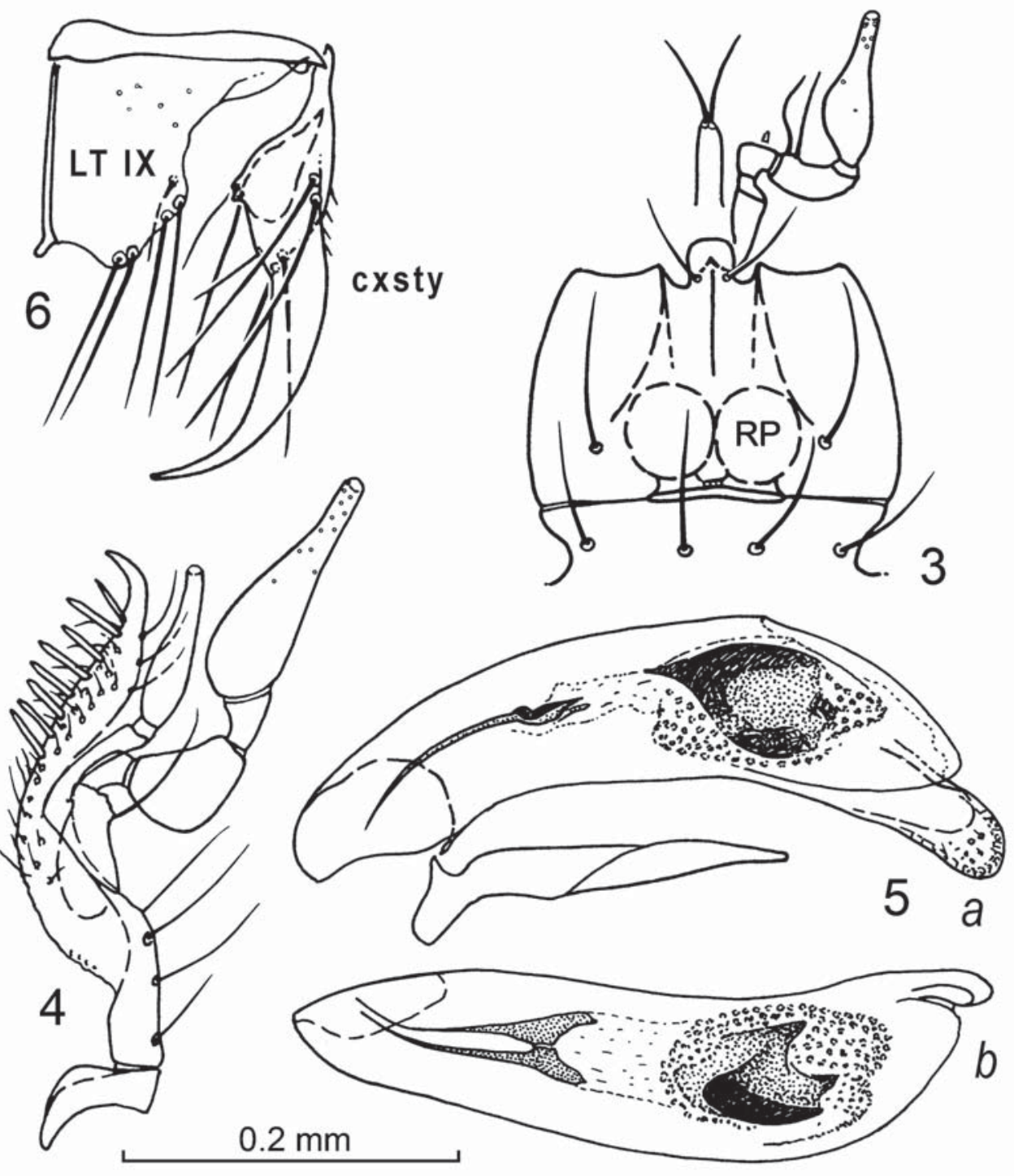

Figs 3-6. Leleuporella tuberculata sp.n.: labium (3), right maxilla (4), aedeagus, left lateral aspect (5a) and right dorsolateral aspect (5b), right female laterotergite IX and coxostylus (6); cxsty - coxostylus, LT IX - laterotergite IX, RP — ringed pore.

Рис. 3-6. Leleuporella tuberculata sp.n.: нижняя губа (3), правая максилла (4), эдеагус, вид слева (5а) и справа-сверху (5b), правые латеротергит IX и коксостилюс (6); cxsty — коксостилюс, LT IX — латеротергит IX, RP — кольцевидная пора.

conspicuous, almost straight, well visible from above due to propleura strongly tumid in basal two thirds; side border obliterate. Constricted pronotal base, or basal flange, sinuate at middle of back margin, widely and deeply sulcate in front of a sharp submarginal carina; latter bearing four small but sharp tubercles subequidistant from both each other and side margin, inner ones being smaller.

Elytra 2.04-2.12 (mean 2.07) times as long as wide, 1.19-1.25 (mean 1.22) times as wide as pronotum, truncate basally, nearly parallel-sided in middle third, broadest about two thirds from base; shoulders rounded and only slightly protruding, without humeral denticle. No angle between side and basal borders, latter hardly surpassing stria 4 inwardly. Elytral striae coarsely punctate, subequally deep throughout, shallower at apex. Stria 1 reaching apex, deeper apicad and less so basad, adjoining a large prescutellary setigerous pore situated in a rather wide, rounded swell protruding forward; 2nd and 3rd shallower basally; 6th shallower and more finely punctate than other striae, obsolete in basal forth of elytra. Intervals convex, 4th in apical third about twice as wide as $3 \mathrm{rd}$; intervals 3 and 5 each with a row of over 20 setae almost touching striae 3 and 5, these setae being long and curved inwards, resulting in a comblike chaetome characteristic of the genus. Wings full.

Tarsomere 1 very long, about as long as the remaining tarsomeres combined at least in fore and hind legs; 
tarsomere 5 with a narrow empodium, latter being as long as claws. Protibia with a strong apical spine and three lateral teeth; of them, proximal tooth very small, middle one larger and sharp, distal tooth large and bearing a seta behind the middle; movable spur narrow, almost straight, about as long as apical spine. Meso- and metatibiae with many long setae; apical spurs subequally very long and thin, nearly setiform, only a little shorter than tarsomere 1 . Femora with numerous short setae dorsally and much longer clinging setae over anterior (functionally, ventral) surface. Protrochanter ventro-apically extended into a sharp denticle.

Aedeagus (Fig. 5): penis with basal orifice shifted to its right side, apical lamella large and widely rounded, left paramere moderately long and asetose, right paramere totally reduced; endophallic basal sclerite well-developed X-shaped.

Female coxostylus as in Fig. 6.

DIAGNOSIS. The present species is closest to $L$. devagiriensis which differs by smaller body, by much more narrow mid-line of the pronotum, by more strongly rounded sides of the pronotum and elytra; when measured from apex to their basal slope, these being distinctly shorter, only 1.8 times as long as wide, in the specimen depicted by Abhita \& Sabu [2009]. The main points to distinguish the new species from $L$. sexangulata are as follows: the well-developed eyes, a different sculpture of the head and pronotum, namely, the very deep and broad interocular sulci and the mid-line of the pronotum, the even dorsal surface of the head, as well as the longer elytra with the more strongly rounded shoulders. Particular body size and/or head sculpture, or well-developed eyes discriminate the African congeners.

MATERIAL. Holotype $\sigma^{\top}$, South Vietnam, Dongnai Province, Nam Cat Tien National Park, $11^{\circ} 25^{\prime} 18^{\prime \prime}$ N, 107 $25^{\prime} 44^{\prime \prime}$ E, Expedition of the Joint Russian-Vietnamese Tropical Center, 10.VI.2005, at light of HQL-450 (D. Fedorenko). Paratypes, 6 우, same data, but one 9 taken 3-4.XII.2004.

DISTRIBUTION. While being described from a single locality only, the species is very likely to be more widespread as it is winged and flying well.

HABITATS AND HABITS. No exact data but the specimens of the type series was taken at light together with a few smaller clivinines. These were as follows: Trilophus hispidulus Putzeys, 1866, T. baehri Balkenohl, 1999, T. schmidti Putzeys, 1877, Trilophidius impunctatus Putzeys, 1868, Syleter paradoxus Putzeys, 1868, S. papua Darlington, 1962, and an undescribed Syleter, the former two Trilophus and S. papua being first recorded in Vietnam. The lamp was stationed at the border of a semidesidous monsoon tropical forest, $c a$ $200 \mathrm{~m}$ distant from the right bank of the Dongnai river.

NAME. The name is given due to the pronotal basal flange furnished with four small but distinct tubercles.

COMMENTS. Balkenohl [2001] considered Leleuporella to be a member of the subtribe Reicheiina Jeannel, 1957, as are the genera Trilophus and Trilo- phidius. Yet Leleuporella shows no characters of Reicheiina but a small depigmented body, combined with the polymerous dorsal chaetome on the elytra. All the other its particulars, especially those of the head sculpture and of the structure of the mouthparts, as well as of both male and female genitalia, are characteristic of Clivinina, Syleter and some Clivina, first. Especially noteworthy are such characters as deep or very deep interocular sulci, a transverse frontoclypeal suture, strong and lobate median tooth of mentum, large ringed pores which conjointly open up in the suture between the mentum and the submentum, and the endophallus supplied with a well-developed X-shaped sclerite. In addition, Leleuporella shows the elytral dorsal setae situated in striae 3 and 5 instead of on the respective elytral intervals, the former pattern being peculiar rather to Clivinina, e.g. Sparostes, than to Reicheiina.

Striganoviella Fedorenko, gen.n. Figs 2, 7-10.

Type species: Striganoviella subopaca Fedorenko, sp.n., designated here.

DESCRIPTION. Body (Fig. 2) small, a little shining due to a conspicuous microsculpture composed of isodiametric meshes.

Eyes large, clypeus flat, with a sharp transverse carina posteriorly, anterior margin of clypeus hardly convex, bordered, clypeofrontal suture wide, moderately deep, limited behind by a sharp, transverse, frontal carina arcuated forward a little and extended on each side into a not quite regular longitudinal carina, these diverging backwards and running parallel to sharp supraocular ones, frons rugose on disc, head neither punctate nor striolate near back eye margin. Labrum 7setose, with strongly emarginate anterior margin and rather lobate front angles. Mentum (Fig. 7) fused to submentum, with no traces of suture in between; ringed pores very small and probably not functioning, their openings almost indistinct. But one, anterior, pair of setae, on mentum, situated at base of median tooth, lateral setae lacking. Submentum with one, medial, pair of setae situated in a deep, transverse, oval, basal depressions. Ligula moderately wide, bisetose, shorter than paraglossae; penultimate labial palpomere bisetose at inner margin, last labial palpomere tumid medially, with large sensorial field extended to its apex; last maxillary palpomere of similar shape, but narrower and without sensorial field. Maxilla similar to that of Dyschiriodes Jeannel, 1941 or Dyschirius Bonelli, 1810

Pronotum about as wide as long, both antero- and posterolateral setigerous pores present, side border entire, slightly surpassing posterolateral setigerous pore, mid-line well-developed, anterior transverse depression (V-shaped furrow) reduced, anterior margin closely longitudinally striolate.

Winged? Elytra subcylindric, basal border fine but distinct, obliterated near suture, where an almost indis- 

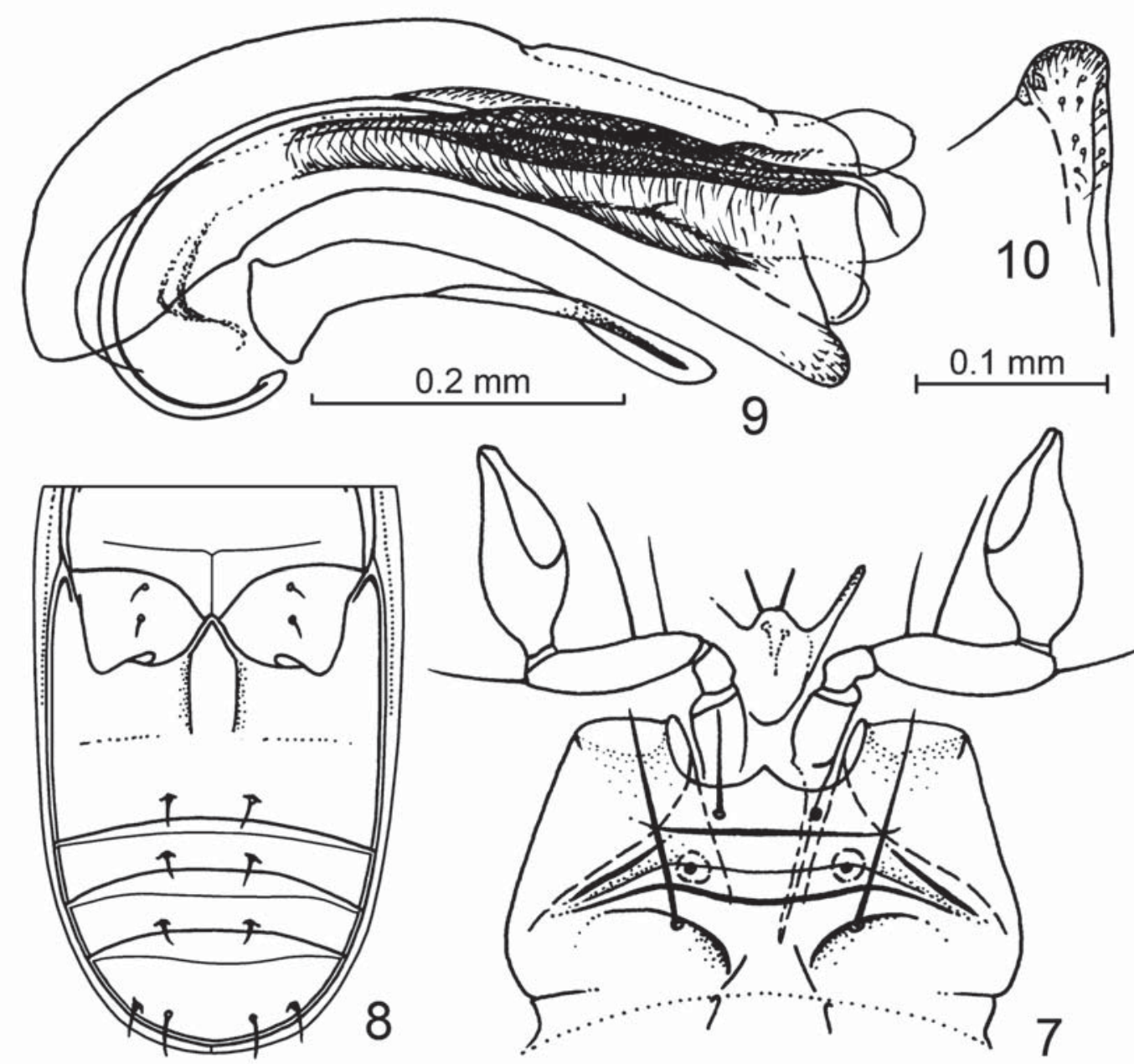

9

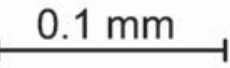

. 
ture of the $3^{\text {rd }}$ abdominal sternite, since the remaining genera show no medial concavity, combined with the intercoxal borders strongly diverging between and conspicuously diverging behind the metacoxae. The latter are separate in addition, which is characteristic of the Dyschiriini but Dyschirius Bonelli, 1810, and almost all Dyschiriodes. A conspicuous isodiametric microsculpture over the entire dorsum is observed rather rarely, namely, in Akephorus, some Dyschirius and few Dyschiriodes. A rugose head combined with the pronotum longitudinally striate at its front margin is what distinguishes Clivinopsis from the other dyschiriines. The former character is observable in some Dyschiriodes as well, the clypeus transversely carinate before the frontoclypeal suture being characteristic of Paradyschirius first. It was the latter taxon alone that could be selected among the others as a probable relative of Striganoviella. However, this follows from nothing else but the combination of the transversely carinate clypeus and a more or less similar structure of the aedeagus, whereas the remaining features, including rather short flagellum of the penis, seem to be not so.

NAME. The genus is named in the honour of an eminent soil zoologist and entomologist, my teacher and colleague, Prof. B.R. Striganova.

\section{Striganoviella subopaca Fedorenko, sp.n.}

DESCRIPTION. Body small, 2.9 mm long, bronzed dorsally, reddish-brown beneath, legs, antennae and mouthparts dark brown to reddish-brown, mandibles and basal palpomeres red.

Pronotum 1.01-1.04 times as wide as long, subglobose, strongly and equally rounded on sides, with anterior margin convex and small but sharp front angles. Mid-line very distinct, moderately deep, slightly deeper before base. Elytra subcylindric, 1.12-1.17 times as wide as pronotum, 1.86-1.92 times as long again as wide, rather strongly oblique from peduncle to humeri, widest before middle, slightly more strongly narrowing backward than forward, widely rounded apically; basal margin convex a little, shoulders rounded, without tooth. Elytral striae deep, almost engraved, impunctate, increasingly shallow both outwards and forwards starting from level of anterior (d1) setigerous pore, finely punctate where shallow, 1 . to 3 . almost obsolete basally, $5(6)$. to 8 . so in basal three fifth, each arranged into a row of sparse punctures; intervals subconvex before apex, otherwise flat. Protibia with apical spine moderately long, almost straight, blunt apically, slightly bent backwards at its base, not bent inwards, distal marginal tooth rather large, proximal one small and wide; movable apical spur nearly straight, a little shorter than apical spine, as long as about 2.5 basal tarsomeres.

MATERIAL. Holotype $\sigma^{7}$, N-Vietnam, $\sim 25 \mathrm{~km}$ E of Hai Phong, Cat Ba Natn. Park, 2048' N, 106 57' E, 20.X.2011 (D. Fedorenko). Paratype + , same data.

HABITATS AND HABITS. Both specimens have been collected in bare sand clay among mangrove stands at the sea shore, together with Dyschiriodes (s.str.) kaliki (Kult, 1949), Bembidion (Microserrulula) xanthacrum (Chaudoir, 1850) and an undescribed B. (Eurytrachelus).

\section{Acknowledgements}

I am very obliged to all Russian and Vietnamese colleagues who accompanied me during the expeditions of The Joint Russian-Vietnamese Tropical Research in Vietnam and to Dr. M. Balkenohl for his kindly revising the manuscript.

\section{References}

Abhita P., Sabu T.K. 2009. Rare ground-beetle species of Leleuporella Basilewsky (Coleoptera: Carabidae: Scaritinae: Scaritini) from Indian sub-continent // Zootaxa. No.2310. P. 5963.

Balkenohl M. 1997. Leleuporella sexangulata sp. n. from Sri Lan$\mathrm{ka}$, a Leleuporella species outside the Ethiopian realm (Coleoptera, Carabidae). // Revue suisse de Zoologie. T.104 Fasc.3. P.605-609.

Balkenohl M. 2001. Key and catalogue of the tribe Clivinini from the Oriental realm, with revisions of the genera Thliboclivina Kult and Trilophidius Jeannel (Insecta, Coleoptera, Carabidae, Scarititae, Clivinini). Sofia-Moscow: Pensoft Publs. 83 p.

Basilewsky P. 1956. Coléoptères recueilis par N. Leleup au Lac Tumba. I. Carabidae // Revue de zoologie et botanique Africaines. T.53. Fasc.3-4. P.418-434.

Fedorenko D.N. 1996. Reclassification of world Dyschiriini, with a revision of the Palearctic fauna (Coleoptera, Carabidae). Sofia-Moscow-St. Petersburg: Pensoft Publs. 224 p. 